\title{
Life at the margin: the mating system of Mediterranean conifers
}

\author{
Gwendal Restoux, Daniel E. Silva, Fabrice Sagnard, Franck Torre, Etienne Klein and Bruno Fady
}

Restoux, G., Silva, D. E., Sagnard, F., Torre, F., Klein, E. and Fady, B. 2008. Life at the margin: the mating system of Mediterranean conifers. - Web Ecol. 8: 94-102.

Mixed mating, where a single tree progeny results from a mixture of selfing and outcrossing, is widespread in conifers and could be an evolutionary advantage at ecological margins when mating partners become scarce. This study analyzes how the mating system responds to bioclimate and density variations. We surveyed published data on the mating system of Abies, Picea and Pinus species when information on bioclimate and stand density was available. Our survey revealed that Mediterranean species demonstrate a lower selfing rate than other species and that the proportion of selfed versus outcrossed progeny is not fixed within species. The highest variability in mating types within populations was found when stand density was the most variable.

To show how density affects the proportion of selfed versus outcrossed progeny, we used isozymes to genotype single tree seeds from a marginal Abies alba forest in Mediterranean France (Mont Ventoux) where low-to high-density stands are found. We then tested the adaptive potential of the different high and low density progenies by sowing them under controlled nursery conditions and measuring germination rate and seedling survival after 4 years under 3 different water regimes. Although the mean value of outcrossing rate was typical for mixed mating conifers $\left(t_{m}=0.85\right)$, individual outcrossing rates varied from 0.05 to 0.99 and were strongly correlated with stand type and density ( $\mathrm{t}_{\mathrm{m}}$ from 0.87 in high-density to 0.43 in low-density marginal stands). Significantly fewer seeds from the low density marginal stand germinated (32\% vs $53 \%$ in the high density mature stand), although seedlings from the marginal stand had a better 4-year survival (81\%) than seedlings from the high-density mature stand (63\%) when the three water regimes (from least to most stressful) were averaged.

Trees from low density stands may be at a selective disadvantage because they produce more selfed progeny than trees from high-density stands. However, selfed seeds may be purged early on (at the embryo stage) and the remaining seeds tend to produce seedlings with better fitness. Variability of the selfing rate might thus be an adaptive strategy for species in highly contrasted environments where selection of both reproductive assurance and avoidance of inbreeding depression may be density dependent.

G. Restoux, F Sagnard and B. Fady (fady@avignon.inra.fr), INRA, UR629, Ecologie des Forêts Méditerranéennes (URFM), Domaine St Paul, FR-84914 Avignon cedex, France. - D. E. Silva and F. Torre, IMEP, UMR CNRS 6116, Univ. Paul Cézanne Aix-Marseille III, Europôle Méditerranéen de l'Arbois, B.P. 80, FR-13545 Aix-en-Provence cedex 04, France. - E. Klein, INRA, UR546, Biostatistique et Processus Spatiaux, Domaine St Paul, FR-84914 Avignon cedex, France. - D. E. Silva also at: INRA, UMR Écologie et écophysiologie forestières, FR-54280 Champenoux, France. -F. Sagnard also at: ICRISAT/CIRAD, clo Campus ICRAF, PO Box 39063, Nairobi, Kenya.

Accepted 23 June 2008

Copyright (C) EEF

ISSN 1399-1183 
The study of reproduction in plants encompasses a wide range of different processes, from flower and seed fecundity to mating barriers, from the scale and shape of pollen and seed flow to the frequency of long-distance dispersal (Griffin and Sedgley 1989). These processes are traditionally analyzed either from a population genetics or an ecological perspective (Cheptou and Schoen 2007). From the population genetics perspective, the mating system is a complex trait that affects the expression of selective forces. By increasing heterozygosity, outcrossing increases the effective rate of recombination by mixing non-related genomes (promoting the spread of beneficial alleles and consequently the purge of deleterious ones) while selfing increases the expression of genetic load (and subsequently the purge of deleterious recessive mutations). Mixed mating, in which a single tree progeny results from a mixture of selfing and outcrossing, is widespread in plants, although its maintenance remains an evolutionary puzzle (Goodwillie et al. 2005).

On the one hand, if selfing is advantageous (because two copies of the same genes are transmitted to the progeny instead of just one, Fisher 1941), alleles responsible for selfing should spread and become fixed in the population. On the other hand, if selfing is disadvantageous (because of inbreeding depression following the appearance of deleterious alleles at a homozygous state), selfing alleles should disappear from the population. However, because the genetic load is purged by selfing, either complete outcrossing or complete selfing should be evolutionary stable strategies depending on the relative fitness of selfed versus outcrossed progeny (Lande and Schemske 1985).

Several theories have been proposed to explain the widespread co-existence of both selfing and outcrossing within individuals, populations and species: spatial and temporal variability of inbreeding depression, pollen quantitydependant outcrossing rate ('mass action' and 'pollen discounting') and reproductive assurance (Holsinger 1991, Porcher and Lande 2005; reviewed by Goodwillie et al. 2005, Cheptou and Schoen 2007).

The reproductive assurance hypothesis explains why mixed mating may be conserved states where there is a need to balance the cost of producing selfed seeds (suffering from inbreeding depression) with the cost of producing no seeds at all when partners (or pollinators) become scarce, while still maintaining the potential to produce outcrossed seeds (with limited inbreeding depression) when partners (or pollinators) are plentiful (reviewed by Cheptou and Schoen 2007). Empirical evidence demonstrating larger seed-sets for mixed mating versus strictly outcrossing individuals in low density populations is still very limited (Cheptou and Dieckmann 2002, Kalisz et al. 2004).

Mixed mating is widespread in trees, particularly in conifers (Mitton 1992). Although conifers have various life history traits, most are wind-pollinated and monoecious, which can lead to automatic selfing due to geitonogamy. Furthermore, they colonize a wide range of (often se- vere) environments (from boreal to tropical) to which they have adapted since their emergence in the Carboniferous (DiMichele et al. 2001) and where their population densities have varied considerably. Therefore, they are a good model to test whether or not demography (and thus mate availability) can affect reproductive output and whether selfing contributes to reproductive assurance at low densities. For example, Robledo-Arnuncio et al. (2004) showed that low-stand density significantly increased both the proportion of selfed progeny and the rate of empty seeds due to inbreeding depression in the mixed mating conifer Pinus sylvestris.

Here, we test and discuss the hypothesis that reproductive assurance can be an evolutionary advantage at a species' ecological margin when and where potential mates become scarce (low census and/or low density). First, we analyze how bioclimatic and density variations can affect variability in the mating system using a set of published data compiled for conifers. We focused our attention on the Mediterranean area, where we expected to find strong local variations in population spatial structure due to the high geographical, climatic and environmental heterogeneity of this biome (Blondel and Aronson 1999). Second, we used original data to show how stand density affects the selfing rate, inbreeding depression and survival potential of Abies alba, a mixed mating European conifer that has numerous marginal populations under the Mediterranean climate (Quézel and Médail 2003).

\section{Material and methods}

We first conducted a survey of published data on the mating system of conifers, restricting our research to the three genera Abies, Picea and Pinus (where all species are mixed mating), where information on bioclimate (using 3 classes defined as Mediterranean, $\mathrm{M}$, non-Mediterranean, $\mathrm{nM}$, and non-Mediterranean but at the rear-edge of the natural distribution area, $\mathrm{nM}-\mathrm{r}$ ) and stand density were available. We collected 6, 30 and 10 studies dealing with $\mathrm{M}, \mathrm{nM}$ and nM-r species, respectively. From these data, we computed the mean, minimum and maximum values of the average outcrossing rate $\left(t_{m}\right)$ within each study (Table 1 ). We considered that $\mathrm{t}_{\mathrm{m}}$ values greater than 1 were due to aberrations (MLTR or MLTF, Ritland 2002), and thus made them equal to 1 for all computations of outcrossing ranges and means. We attributed a density level to each population and classified studies according to species (Table 1). We separated density into 3 levels: high (3), medium (2) and low (1). We relied on authors' estimates of what they considered low, medium or high density for the species studied. For Abies alba, we considered that stand density was (i) low when adult trees were fewer than 25 per hectare, (ii) medium when adult trees were between 25 and 100 per hectare and (iii) high when density was over 100. The definition of these density classes is based on our own 
Table 1. Comparison of mean outcrossing rates $\left(\mathrm{t}_{\mathrm{m}}\right)$ in Abies, Piced and Pinus species in relation to bioclimate and mean population densities. Values of $\mathrm{t}_{\mathrm{m}}$ in parenthesis are population extremes. An absence of population extremes indicate that only a single population was investigated. Values of $\mathrm{t}_{\mathrm{m}}$ are estimated using isozyme or DNA markers and seed material, except Sorensen (1994) who used phenotypic markers. $\mathrm{M}=$ Mediterranean, $\mathrm{nM}=$ non-Mediterranean, $\mathrm{nM}-\mathrm{r}=$ 'rear edge' Mediterranean distribution of a typically non-Mediterranean species, ${ }^{*}=$ seed orchard.

\begin{tabular}{|c|c|c|c|c|c|}
\hline Species & Bioclimate & Stand density & $\mathrm{t}_{\mathrm{m}}$ & Geographic origin & Reference \\
\hline Abies alba & $\mathrm{nM}-\mathrm{r}$ & low to high & $0.72(0.43-0.87)$ & Medit. France & This study \\
\hline Abies alba & $\mathrm{nM}$ & medium to high & $0.89(0.68-1.00)$ & German Alps & Schroeder 1989 \\
\hline Abies amabilis & $\mathrm{nM}$ & medium to high & $0.82(0.80-0.84)$ & W. Canada & El-Kassaby et al. 2003 \\
\hline Abies balsamea & $\mathrm{nM}$ & medium to high & $0.89(0.78-0.99)$ & E. USA & Neale and Adams 1985 \\
\hline Abies borisii regis & M & high & 0.94 & Greece & Fady and Westfall 1997 \\
\hline Abies lasiocarpa & $\mathrm{nM}$ & medium to high & $0.89(0.65-0.94)$ & Colorado, USA & Shea 1987 \\
\hline Abies procera & $\mathrm{nM}$ & high & $0.94(0.90-0.98)$ & Denmark $\left(^{*}\right)$ & Siegismund and Kjaer 1997 \\
\hline Picea abies & $\mathrm{nM}$ & medium to high & $0.95(0.95-0.96)$ & Italy & Morgante et al. 1991 \\
\hline Picea abies & $\mathrm{nM}$ & medium & $0.83(0.82-0.84)$ & Italy & Boscherini et al. 1993 \\
\hline Picea breweriana & $\mathrm{nM}-\mathrm{r}$ & low to high & $0.87(0.75-1.00)$ & California, USA & Ledig et al. 2005 \\
\hline Picea chibuabuana & $\mathrm{nM}-\mathrm{r}$ & low & $0.08(0.00-0.15)$ & Mexico & Ledig et al. 1997 \\
\hline Picea engelmanii & $\mathrm{nM}$ & medium to high & $0.86(0.78-0.96)$ & Colorado, USA & Shea 1987 \\
\hline Picea glauca & $\mathrm{nM}$ & low to high & $0.90(0.89-0.92)$ & Ontario, Canada & O’Connell et al. 2006 \\
\hline Picea glauca & $\mathrm{nM}$ & medium & $0.73(0.70-0.76)$ & E Canada & Innes and Ringius 1990 \\
\hline Picea mariana & $\mathrm{nM}$ & medium to high & $0.72(0.63-0.83)$ & Alberta, Canada & Sproule and Dancik 1996 \\
\hline Picea mariana & $\mathrm{nM}$ & high & $0.93(0.89-0.98)$ & Eastern Canada & Boyle and Morgenstern 1986 \\
\hline Picea martinezii & $\mathrm{nM}-\mathrm{r}$ & low to medium & $0.56(0.40-0.69)$ & Mexico & Ledig et al. 2000 \\
\hline Picea mexicana & $\mathrm{nM}-\mathrm{r}$ & low to high & $0.68(0.59-0.81)$ & Mexico & Ledig et al. 2002 \\
\hline Picea omorika & $\mathrm{nM}-\mathrm{r}$ & medium to high & $0.95(0.84-1.02)$ & Serbia & Kuittinen and Savolainen 1992 \\
\hline Picea rubens & $\mathrm{nM}$ & low to high & $0.60(0.53-0.65)$ & E Canada & Rajora et al. 2000 \\
\hline Picea sitchensis & $\mathrm{nM}$ & medium to high & $0.86(0.65-0.97)$ & W Canada and USA & Mimura and Aitken 2007 \\
\hline Pinus albicaulis & $\mathrm{nM}$ & medium to high & $0.86(0.73-0.98)$ & W Canada and USA & Bower and Aitken 2007 \\
\hline Pinus attenuata & M & high & 0.96 & California, USA & Burczyk et al. 1996 \\
\hline Pinus banksiana & $\mathrm{nM}$ & high ? & $0.89(0.83-0.95)$ & Ontario, Canada & Fu et al. 1992 \\
\hline Pinus brutia & M & high & $0.95\left(^{*}\right)$ & Turkey & Kaya et al. 2006 \\
\hline Pinus cembra & $\mathrm{nM}$ & low & 0.69 & Ukraine & Krutovskii et al. 1995 \\
\hline Pinus cembra & $\mathrm{nM}$ & high & 0.81 & Italy & Lewandowski and Burczyk 2000 \\
\hline Pinus chiapensis & $\mathrm{nM}$ & medium to high & $0.87(0.49-1.20)$ & Mexico & Del Castillo and Trujillo 2008 \\
\hline Pinus contorta & $\mathrm{nM}$ & high & $0.95(0.93-0.98)$ & Alberta, Canada & Perry and Dancik 1986 \\
\hline Pinus greggii & $\mathrm{nM}$ & high & $0.97(0.92-1.00)$ & Mexico & Parraguirre-Lezama et al. 2004 \\
\hline Pinus jeffreyi & $\mathrm{nM}$ & medium to high & $0.94(0.88-0.97)$ & Oregon, USA & Furnier and Adams 1986 \\
\hline Pinus kesyia & $\mathrm{nM}$ & low to high & $0.83(0.68-0.97)$ & Thailand & Boyle et al. 1991 \\
\hline Pinus koraiensis & $\mathrm{nM}$ & high & $0.97(0.92-1.03)$ & Far east Russia & Krutovskii et al. 1995 \\
\hline Pinus leucodermis & M & medium to high & $0.77(0.72-0.82)$ & Italy & Morgante et al. 1993 \\
\hline Pinus maximartinezii & $\mathrm{nM}-\mathrm{r}$ & low to medium & $0.82(0.44-0.97)$ & Mexico & Ledig et al. 1999 \\
\hline Pinus merkusii & $\mathrm{nM}$ & high & $0.87\left(^{*}\right)$ & Indonesia & \multirow{2}{*}{$\begin{array}{l}\text { Siregar and Hattemer } 2001 \\
\text { Changtragoon and Finkeldey } \\
1995\end{array}$} \\
\hline Pinus merkusii & $\mathrm{nM}$ & low to high & $0.47(0.02-0.84)$ & Indonesia & \\
\hline Pinus pinaster & M & high & $0.98(0.95-1.00)$ & Spain & De Lucas et al. 2008 \\
\hline Pinus pinceana & $\mathrm{nM}-\mathrm{r}$ & medium & $0.87(0.84-0.90)$ & Mexico & Ledig et al. 2001 \\
\hline Pinus ponderosa & $\mathrm{nM}$ & high & $0.91(0.8-0.92)$ & NW USA & Sorensen 1994 \\
\hline Pinus radiata & M & medium to high & $0.96(0.9-1.00)$ & $\begin{array}{l}\text { Callfornia and } \\
\text { Mexico }\end{array}$ & Vogl et al. 2002 \\
\hline Pinus sibirica & $\mathrm{nM}$ & high & $0.89(0.82-0.98)$ & Siberia & Krutovskii et al. 1995 \\
\hline Pinus strobus & $\mathrm{nM}$ & medium to high & $0.93(0.87-0.99)$ & Canada & Rajora et al. 2002 \\
\hline Pinus sylvestris & $\mathrm{nM}-\mathrm{r}$ & low to high & $0.93(0.75-0.99)$ & Spain & Robledo et al. 2004 \\
\hline Pinus sylvestris & $\mathrm{nM}$ & high & $0.98(0.96-0.99)^{*}$ & Poland & Burczyk 1998 \\
\hline Pinus washoensis & $\mathrm{nM}-\mathrm{r}$ & medium to high & $0.86(0.76-0.92)$ & Nevada, USA & Mitton et al. 1997 \\
\hline
\end{tabular}


observations of natural stands in our study site (Mont Ventoux), where a significant spatial genetic structure was observed on a progeny when density was below 25 trees per ha (Sagnard 2001). From this data set, we estimated the variability of outcrossing rates between stands for each study by subtracting the minimum $\mathrm{t}_{\mathrm{m}}$ value observed in the study from the maximum one. We also estimated the variability of stand density for each study: from one, when there was only one density class, to three, when density ranged from low to high. We tested the effect of bioclimate ( $\mathrm{M}$ vs $\mathrm{nM}$ and $\mathrm{nM}-\mathrm{r}$ either individually or grouped in a single non-Mediterranean class) on average outcrossing rate for each study, using a non-parametric ANOVA (Kruskal-Wallis rank sum test), because we could not test for variance equality. We also tested the relationship between stand density and the average outcrossing rates of stands using the same Kruskall-Wallis rank sum test.

Secondly, we used isozymes to investigate the genetic composition of individual progeny from a marginal Abies alba population growing under Mediterranean climate in a southeastern French mountain (Mont Ventoux, $\left.44^{\circ} 10^{\prime} \mathrm{N}, 5^{\circ} 15^{\prime} \mathrm{E}\right)$. Mont Ventoux is characterized by stands of different ages, from old-growth relictual stands to young stands where Abies alba has recolonized grazing areas abandoned in the late 19th century. Stands are also characterized by contrasting mature tree densities, from low (fewer than 25 trees per hectare in recolonized areas) to high (more than 100 trees per hectare in old, mature stands). We collected seeds from 52 trees from 4 different stands (Fig. 1): two high-density old-growth stands (HD1 and HD2), one medium-density old-growth stand at the periphery of an old-growth high-density stand, MD, and one low-density recolonizing stand (LD). A set of 7 polymorphic Mendelian isozymes developed for Abies alba was used on embryos, following the standard extraction, electrophoresis and scoring protocols of Fady et al. (1999). A total of 842 seeds were used to assess selfing rate and pollen pool composition using the MLTR software (Ritland 2002). We computed selfing rates for each sampled

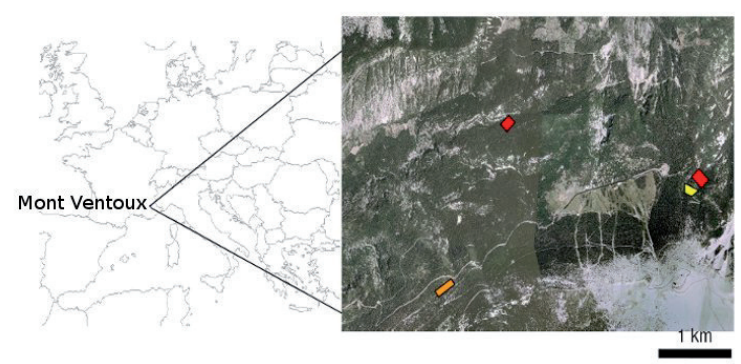

Fig.1. Localization of Mont Ventoux at the European scale and localization of the stands analyzed within Mont Ventoux: high density mature stands HD1 and HD2 (in red), medium density peripheral stand MD (in orange) and low density recolonizing stand LD (in yellow). individual in LD and MD stands but only for stand level in HD1 and HD2 stands.

Finally, we tested early inbreeding depression and survival potential of the different progenies by sowing them under controlled nursery conditions and measuring germination rate and seedling survival after a 4-year period. A subset of 32 seed trees originating either from the HD1 or LD stands was used for this experiment. Germination rate, i.e. the proportion of seeds in each progeny which produced a $5 \mathrm{~mm}$ long emerging radicle after stratification ( 6 weeks at $+4^{\circ} \mathrm{C}$ in moist peat), was measured for all collected seeds (from 215 to 1790 seeds per tree). From these seed lots, 2400 germinated seeds (i.e. 75 seeds per seed tree) were planted in the nursery, using 9 complete blocks and a randomized progeny design within blocks. Three groups of 3 blocks each received different water regimes: drought (Wilting point, $\mathrm{Wp}=3-3.5$ ), light water stress $(\mathrm{Wp}=2.7)$ and normal watering $(\mathrm{Wp}=1.5)$. Progeny survival was measured each year for 4 years. Significance of germination rate and of survival was tested using a logistic regression within an analysis of deviance ('glm' function in R).

All statistical analyses were carried out using the R software, R Development Core Team.

\section{Results}

Our literature survey of conifer trees showed that the variability in the mating system of genera Abies, Picea and Pinus were highly variable among populations and species. The average $t_{m}$ for each bioclimatic class was $0.92,0.84$ and 0.70 for Mediterranean (M), non-Mediterranean (nM) and non-Mediterranean rear-edge (nM-r) species or populations, respectively. There was a significant difference of $\mathrm{t}_{\mathrm{m}}$ between the three bioclimatic classes $\left(\mathrm{Chi}^{2}=9.13, \mathrm{DF}=\right.$ $2, p=0.01$, Fig. 2). Furthermore, there was a significant difference between the average $t_{\mathrm{m}}$ over Mediterranean type species $\left(t_{m}=0.92\right)$ and over non-Mediterranean species, including both $\mathrm{nM}$ and $\mathrm{nM}-\mathrm{r}$ species, $\left(\mathrm{t}_{\mathrm{m}}=0.81\right)\left(\mathrm{Chi}^{2}=\right.$ $5.68, \mathrm{DF}=1, \mathrm{p}=0.017)$. A significantly higher outcrossing rate was found when stand density was higher $\left(\mathrm{Chi}^{2}\right.$ $=23.81, \mathrm{DF}=4, \mathrm{p}<0.0001$, Fig. 3). Further, we found a general trend toward a higher $\mathrm{t}_{\mathrm{m}}$ range in marginal populations (Fig. 4), although this could not be tested as this range was mainly dependent on the number of stands sampled in each study. Finally, a higher $\mathrm{t}_{\mathrm{m}}$ range was observed when the density range was higher $\left(\mathrm{Chi}^{2}=13.88, \mathrm{DF}=2\right.$, $\mathrm{p}=0.001$, Fig. 5).

Our isozyme data showed that the mean multi-locus outcrossing rate $\left(\mathrm{t}_{\mathrm{m}}\right)$ of the Mont Ventoux Abies alba population over the 4 stands was 0.72 (Table 1 ). However, although trees were in the same meso-environment, there were considerable differences in mean stand and individual outcrossing rates. Within the old growth stands HD1 and HD2 (tree density $>100 \mathrm{ha}^{-1}$ ), average $\mathrm{t}_{\mathrm{m}}$ were 0.85 


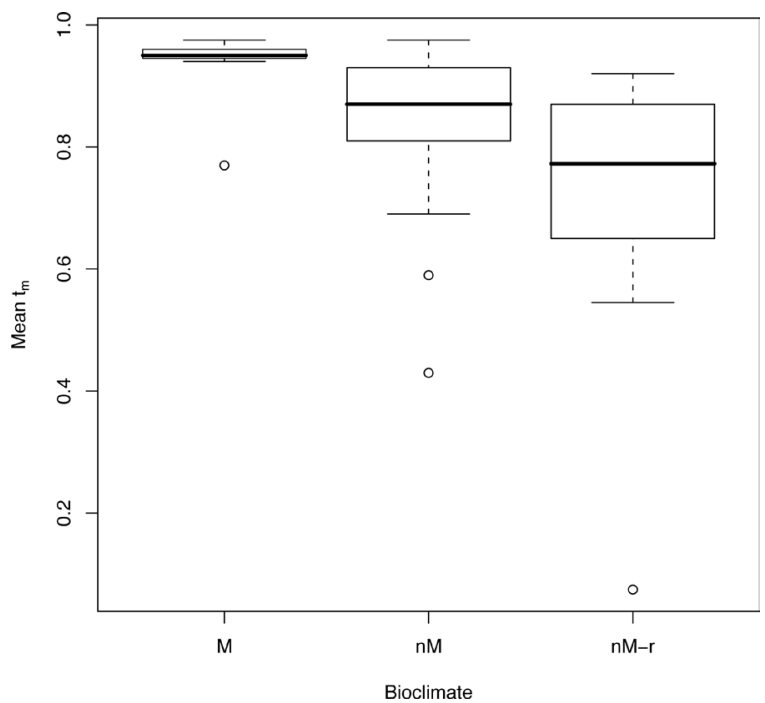

Fig. 2. Outcrossing rates over three bioclimates (Mediterranean, $\mathrm{M}$, non-Mediterranean, $\mathrm{nM}$, and rear edge non-Mediterranean nM-r) in Abies, Picea and Pinus species worldwide.

and 0.87 , respectively. At stand edge, $\mathrm{t}_{\mathrm{m}}$ decreased to 0.71 within the medium density mature stand (MD), with individual values ranging from 0.45 to 0.99 . In the marginal low density recolonizing stand LD (density $\left.<30 \mathrm{ha}^{-1}\right), \mathrm{t}_{\mathrm{m}}$ was 0.43 (individual values from 0.05 to 1.18 ). We found no difference in pollen pool genetic diversity between the different stands $\left(\mathrm{H}_{\mathrm{e}}\right.$ from 0.141 to 0.162$)$.

Significantly fewer seeds from the low density marginal stand LD were able to germinate: $33.8 \%$ vs $52.3 \%$ in the

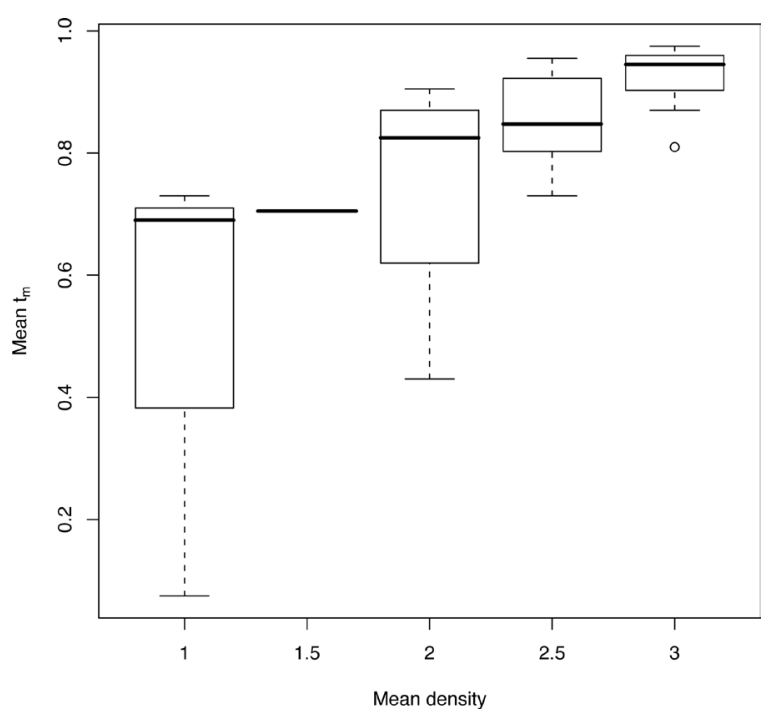

Fig. 3. Effect of density on outcrossing rate at the population level over three genera Abies, Picea and Pinus.

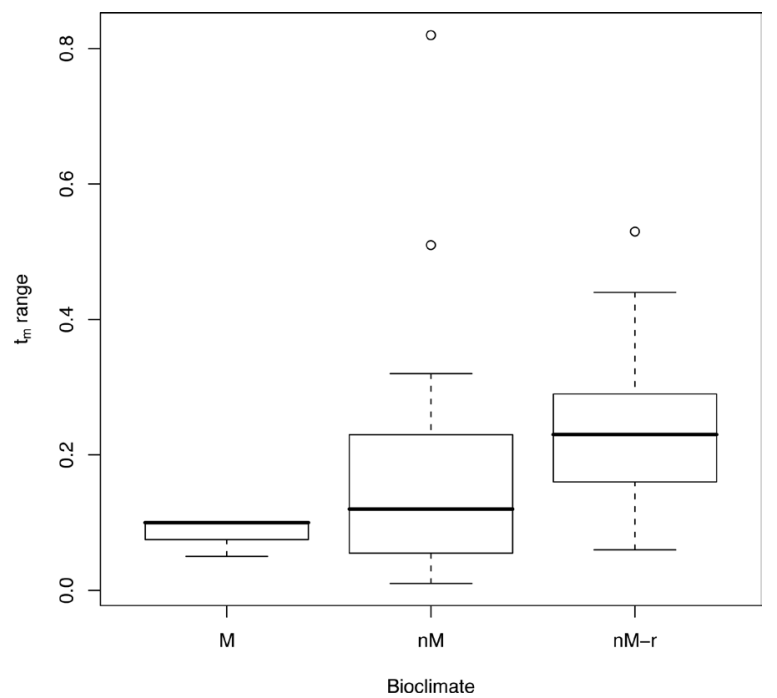

Fig. 4. Outcrossing rate variability among populations over three bioclimates (Mediterranean, $\mathrm{M}$, non-Mediterranean, $\mathrm{nM}$, and rear edge non-Mediterranean, nM-r) in Abies, Picea and Pinus species worldwide.

old-growth high-density stand HD1 $(\mathrm{F}=18.09, \mathrm{DF}=30$, $\mathrm{p}=0.0002$, Table 2). However, seedlings from LD had an overall better survival (81\%) than seedlings from HD1 $(63 \%)$ after 4 years $(\mathrm{p}<0.0001)$. The analysis of deviance showed that water regime, stand density type and their interaction with progeny could explain differences in survival $(p<0.0001)$. Survival decreased with water stress for seeds originating from both LD and HD1 (survival rates: $82 \%$ and $73 \%$ for LD and HD1, respectively). Averaging

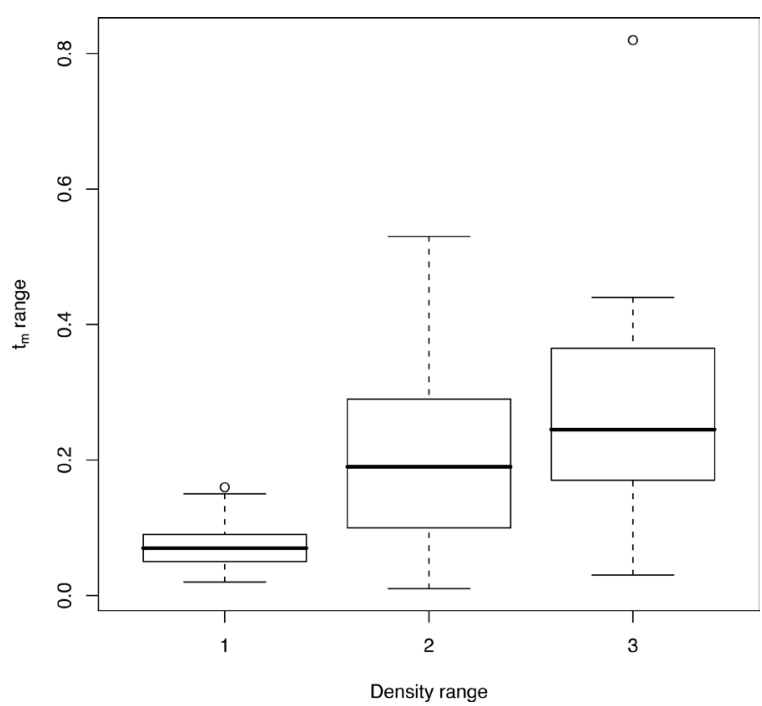

Fig. 5. Outcrossing rate variability versus density variability in Abies, Picea and Pinus species worldwide. 
all three water treatments, LD seedlings had a better survival than HD1 ones. However, this difference is mainly due to the driest water regime (Table 2) and no significant difference between LD and HD1 seedlings was observed under the normal water regime.

\section{Discussion}

For reasons ranging from highly heterogeneous topography to the heterogeneity of land uses due to urbanization and agriculture in highly anthropogenic environments,

Table 2. Germination rate of the 32 seed lots tested according to stand density. Density type: HD = high density, LD = low density.

\begin{tabular}{|c|c|c|c|c|c|}
\hline $\begin{array}{l}\text { Name of } \\
\text { seed tree }\end{array}$ & $\begin{array}{l}\text { Density } \\
\text { type }\end{array}$ & $\begin{array}{l}\text { Total number } \\
\text { of germinated } \\
\text { seeds }\end{array}$ & $\begin{array}{l}\text { Total number } \\
\text { of seeds } \\
\text { tested }\end{array}$ & $\begin{array}{l}\text { Germination } \\
\text { rate in } \%\end{array}$ & $\begin{array}{l}\text { Mortality in \% } \\
\text { after } 4 \text { years } \\
\text { under high } \\
\text { water stress }\end{array}$ \\
\hline s $23 \mathrm{hp}$ & HD & 580 & 995 & 58.29 & 21.9 \\
\hline s $24 \mathrm{hp}$ & $\mathrm{HD}$ & 954 & 1790 & 53.30 & 46.7 \\
\hline s $25 \mathrm{hp}$ & $\mathrm{HD}$ & 838 & 1568 & 53.44 & 16.7 \\
\hline s $26 \mathrm{hp}$ & $\mathrm{HD}$ & 663 & 1251 & 53.00 & 39.3 \\
\hline s $27 \mathrm{hp}$ & HD & 323 & 577 & 55.98 & 29.6 \\
\hline s $28 \mathrm{hp}$ & $\mathrm{HD}$ & 561 & 1296 & 43.29 & 18.2 \\
\hline s $29 \mathrm{hp}$ & $\mathrm{HD}$ & 446 & 826 & 54.00 & 18.5 \\
\hline s $30 \mathrm{hp}$ & HD & 202 & 697 & 28.98 & 18.4 \\
\hline s $31 \mathrm{hp}$ & $\mathrm{HD}$ & 251 & 359 & 69.92 & 25.0 \\
\hline s $32 \mathrm{hp}$ & HD & 414 & 901 & 45.95 & 25.6 \\
\hline s $33 \mathrm{hp}$ & $\mathrm{HD}$ & 622 & 1147 & 54.23 & 41.5 \\
\hline s $34 \mathrm{hp}$ & $\mathrm{HD}$ & 355 & 1089 & 32.60 & 15.7 \\
\hline s $35 \mathrm{hp}$ & HD & 444 & 972 & 45.68 & 15.4 \\
\hline s $36 \mathrm{hp}$ & $\mathrm{HD}$ & 467 & 897 & 52.06 & 9.7 \\
\hline sem $21 \mathrm{hp}$ & $\mathrm{HD}$ & 796 & 1118 & 71.20 & 70.4 \\
\hline sp 22 hp & $\mathrm{HD}$ & 857 & 1280 & 66.95 & 18.2 \\
\hline parc 5 & $\mathrm{LD}$ & 361 & 1367 & 26.41 & 2.5 \\
\hline parc 661 & $\mathrm{LD}$ & 134 & 698 & 19.20 & 11.8 \\
\hline parc 813 & $\mathrm{LD}$ & 158 & 627 & 25.20 & 23.8 \\
\hline s $18 \mathrm{hp}$ & $\mathrm{LD}$ & 338 & 1048 & 32.25 & 12.8 \\
\hline s $19 \mathrm{hp}$ & $\mathrm{LD}$ & 227 & 513 & 44.25 & 21.2 \\
\hline s 4 newhp & $\mathrm{LD}$ & 162 & 460 & 35.22 & 7.1 \\
\hline sem $1 \mathrm{hp}$ & $\mathrm{LD}$ & 123 & 509 & 24.17 & 32.0 \\
\hline sem 12 hp & $\mathrm{LD}$ & 152 & 435 & 34.94 & 14.8 \\
\hline sem $13 \mathrm{hp}$ & $\mathrm{LD}$ & 101 & 351 & 28.77 & 38.9 \\
\hline sem 14 hp & $\mathrm{LD}$ & 463 & 907 & 51.05 & 9.5 \\
\hline sem $17 \mathrm{hp}$ & $\mathrm{LD}$ & 458 & 1212 & 37.79 & 23.1 \\
\hline sem $2 \mathrm{hp}$ & $\mathrm{LD}$ & 65 & 823 & 7.90 & 50.0 \\
\hline sem 20 hp & $\mathrm{LD}$ & 304 & 794 & 38.29 & 4.3 \\
\hline sem $3 \mathrm{hp}$ & $\mathrm{LD}$ & 215 & 610 & 35.25 & 7.7 \\
\hline sem $6 \mathrm{hp}$ & $\mathrm{LD}$ & 591 & 1049 & 56.34 & 8.7 \\
\hline sem 8 hp & $\mathrm{LD}$ & 208 & 595 & 34.96 & 20.0 \\
\hline
\end{tabular}


species distribution areas are typically fragmented in the Mediterranean, thus leading to stands of highly contrasted densities, census and effective sizes (Blondel and Aronson 1999, Fady and Médail 2004). Out of the 9 Abies and 9 Pinus species found in Europe, 13 are Mediterranean endemics and an additional 3 have the 'rear-edge' of their distribution within the Mediterranean bioclimatic zone (Quézel and Médail 2003). Thirteen of these 16 species have patchy distribution areas under Mediterranean conditions. In such heterogeneous environments in terms of density and population size, pollen limitation may be a critical factor for reproduction at fine spatial scale (Restoux et al. unpubl.). Thus, a mixed mating system may be at an evolutionary advantage in such environments, since selfing ensures reproductive assurance when pollen is limited (Knight et al. 2005). On the other hand, pollen discounting, i.e. the cost of selfing due to pollen loss which is not dedicated to outcrossing, favors outcrossing when pollen is not limited (Holsinger 1991).

However, it is not because species live under Mediterranean conditions, characterized by heterogeneity in terms of density, that higher selfing or more variable mating types among and within populations are observed. Mediterranean-type conifers are typically major outcrossers, just like other conifers elsewhere (Table 1). The mean multi-locus outcrossing rate $\left(\mathrm{t}_{\mathrm{m}}\right)$ found for Pinus attenuata in California by Burczyk et al. (1996), for example, is typical for that of mixed-mating conifers, with a low overall level of selfing. What leads to high selfing rates and a high variability in selfing rate is that populations and individuals within populations may experience low and highly variable levels of density, often because they are at the margin of the species distribution area. In Abies alba on the Mont Ventoux, not only does average selfing rate within a stand increase when stand density decreases, but also individual selfing rate variability increases when local density decreases (i.e. when spatial structure becomes more heterogeneous) as shown by Robledo-Arnuncio et al. (2004) for Pinus sylvestris.

Trees from low-density stands may face an uncertain demographic future because they produce both more selfed progeny, subject to inbreeding depression, and more empty seeds, due to pollen limitation and early expression of inbreeding depression, than trees from higher-density stands. However, selfed seeds may be purged early on (at the embryo stage, reviewed by Williams and Savolainen 1996) and the remaining seeds may produce seedlings with better fitness, possibly because of counter-selection of individuals with a higher genetic load (Pichot et al. 2006). This is just what we observed for Abies alba in the Mont Ventoux. Low-density stands (the younger stands) produced fewer viable seeds than high-density (mature) stands, but their fitness, as measured by seedling survival after 4 years in the nursery, was higher, especially under stressful conditions. Also, the fitness reduction at low density caused by inbreeding depression and pollen limitation could be compensated by the demographic advantage of being in an open area where density dependence is weaker (e.g. fate of a gene from the colonization front, Edmonds et al. 2004).

Overall, the pattern observed here is typical of competing self-fertilization (Lloyd 1979), where self-pollen competes with outcross-pollen for pollination, leading to selfing rates governed by a 'mass-action law' (Holsinger 1991): selfing rate is proportional to the ratio of the amount of self-pollen over the total amount of pollen received by stigmas. As a consequence, individuals in low density stands might have a low outcrossing rate because their self-pollen is less diluted within the overall outcrossed pollen. The variability in the mating system in our study is due to obligate selfing in geitonogamous organisms, but we can wonder why such a mating system is conserved if pollen limitation does not occur, since it is costly in terms of fitness (Porcher and Lande 2005). One explanation could be the position of flowers on each tree which may decrease selfing rate because female flowers are located at the top of the crown and exposed to wind-dispersed pollen, whereas male flowers are much below, at the bottom of the crown. On steep slopes, such as those where mountain conifers grow, they are thus much closer to the female flowers of a neighboring seed tree than to their own female flowers. When density decreases, the benefit of selfing as a form of reproductive assurance is thus still possible.

We suggest that the mixed mating system has been conserved as a consequence of the contrasted environments where plants grow, particularly in Mediterranean environments. In such heterogeneous environments, a tradeoff between reproductive assurance, avoidance of inbreeding depression and possible pollen discounting may be selected at different times and places, leading to the maintenance of mixed mating as a viable reproductive strategy.

Acknowledgments - We wish to thank Patrice Brahic and the staff at the State Forest Nursery of Aix en Provence for preparing, installing and measuring the nursery test. This research was made possible by the grant 'Conservation des Ressources Génétiques Forestières' from the French Ministry of Agriculture to INRA. We are very grateful to Julia Fady-Welterlen for her English revision of the whole manuscript.

\section{References}

Blondel, J. and Aronson, J. 1999. Biology and wildlife of the Mediterranean region. - Oxford Univ. Press.

Bower, A. D. and Aitken, S. N. 2007. Mating system and inbreeding depression in whitebark pine (Pinus albicaulis Engelm.). - Tree Genet. Gen. 3: 379-388.

Boyle, T. J. B. et al. 1991. Genetic studies in a tropical pine, Pinus kesiya: III. The mating system in four populations from northern Thailand. - J. Trop. For. Sci. 4: 37-44.

Boyle, T. J. B. and Morgenstern, E. K. 1986. Estimates of outcrossing rates in six populations of black spruce in central New Brunswick. - Silvae Genet. 35: 102-106. 
Boscherini, G. et al. 1993. Mating system analysis in two Italian populations of Norway spruce. - J. Genet. Breed. 47: 45-48.

Burczyk, J. et al. 1996. Mating patterns and pollen dispersal in a natural knob-cone pine (Pinus attenuata Lemmon.) stand. Heredity 77: 251-260.

Burczyk, J. 1998. Mating system variation in a Scots pine clonal seed orchard. - Silvae Genet. 47: 155-158.

Changtragoon, S. and Finkeldey, R. 1995. Patterns of genetic variation and characterization of the mating system of Pinus merkusii in Thailand. - For. Genet. 2: 87-97.

Cheptou, P. O. and Dieckmann, U. 2002. The evolution of selffertilization in density-regulated populations. - Proc. R. Soc. Lond. B 269: 1177-1186.

Cheptou, P. O. and Schoen, D. J. 2007. Combining population genetics and demographical approaches in evolutionary studies of plant mating systems. - Oikos 116: 271-279.

Del Castillo, R. F. and Trujillo, S. 2008. Effect of inbreeding depression on outcrossing rates among populations of a tropical pine. - New Phytol. 177: 517-524

De-Lucas, A. I. et al. 2008. Mating system and pollen gene flow in Mediterranean maritime pine. - Heredity 100: 390-399.

DiMichele, W. A. et al. 2001. Response of late Carboniferous and early Permian plant communities to climate change. Annu. Rev. Earth Plan. Sci. 29: 461-487.

Edmonds, C. A. et al. 2004. Mutations arising in the wave front of an expanding population. - Proc. Natl Acad. Sci. USA 101: 975-979.

El-Kassaby, Y. A. et al. 2003. Genetic evaluation of alternative silvicultural systems in coastal montane forests: western hemlock and amabilis fir. - Theor. Appl. Genet. 107: 598-610.

Fady, B. et al. 1999. Genetic differentiation in Abies alba populations from south-eastern France. - For. Genet. 6: 129-138.

Fady, B. and Médail, F. 2004. Mediterranean forest ecosystems. - In: Burley, J. et al. (eds), Encyclopedia of forest science. Elsevier, pp. 1403-1414.

Fady, B. and Westfall, R. D. 1997. Mating system parameters in a natural population of Abies borisii regis Mattfeld. - Ann. For. Sci. 54: 643-647.

Fisher, R. A. 1941. Average excess and average effect of a gene substitution. - Ann. Eugenics 11:53-63.

$\mathrm{Fu}$, Y. B. et al. 1992. Pollen pool heterogeneity in Jack pine ( $P i-$ nus banksiana Lamb) - a problem for estimating outcrossing rates. - Theor. Appl. Genet. 83: 500-508.

Furnier, G. R. and Adams, W. T. 1986. Mating system in natural populations of Jeffrey pine. - Am. J. Bot. 73: 1002-1008.

Goodwillie, C. et al. 2005. The evolutionary enigma of mixed mating systems in plants: occurrence, theoretical explanations, and empirical evidence. - Annu. Rev. Ecol. Evol. Syst. 36: 47-79.

Griffin, A. R. and Sedgley, M. 1989. Sexual reproduction of tree crops. - London Acad. Press.

Holsinger, K. E. 1991. Mass-action models of plant mating systems: the evolutionary stability of mixed mating systems. Am. Nat. 138: 606-622.

Innes, D. J. and Ringius, G. G. 1990. Mating system and genetic structure of two populations of white spruce (Picea glauca) in eastern Newfoundland. - Can. J. Bot. 68: 1661-1666.

Kalisz, S. et al. 2004. Context-dependent autonomous self-fertilization yields reproductive assurance and mixed mating. - Nature 430: 884-887.
Kaya, N. et al. 2006. Mating system and pollen contamination in a Pinus brutia seed orchard. - New For. 31: 409-416.

Knight, T. M. et al. 2005. Pollen limitation of plant reproduction: pattern and process. - Annu. Rev. Ecol. Evol. Syst. 36: 467-497.

Krutovskii, K. V. et al. 1995. Isozyme study of population genetic structure, mating system and phylogenetic relationships of the five stone pine species (subsection Cembrae, section Strobi, subgenus Strobus). - In: Baradat, P. et al. (eds), Population genetics and conservation of forest trees. SPB Acad. Publ., pp. 280-304.

Kuittinen, H. and Savolainen, O. 1992. Picea omorika is a self fertile but outcrossing conifer. - Heredity 68: 183-187.

Lande, R. and Schemske, D. W. 1985. The evolution of selffertilization and inbreeding depression in plants. I. Genetic models. - Evolution 39: 24-40.

Ledig, F. T. et al. 1997. Recent evolution and divergence among populations of a rare Mexican endemic, Chihuahua spruce, following Holocene climatic warming. - Evolution 51: 1815-1827.

Ledig, F. T. et al. 1999. Evidence for an extreme bottleneck in a rare Mexican pinyon: genetic diversity, disequilibrium and the mating system in Pinus maximartinezii. - Evolution 53: 91-99.

Ledig, F. T. et al. 2000. The mating system and genetic diversity in Martinez spruce, an extremely rare endemic of Mexico's Sierra Madre Oriental: an example of facultative selfing and survival in interglacial refugia. - Can. J. For. Res. 30: 1156-1164.

Ledig, F. T. et al. 2001. Genetic diversity and the mating system of a rare Mexican pinon, Pinus pinceana, and a comparison with Pinus maximartinezii (Pinaceae). - Am. J. Bot. 88: 1977-1987.

Ledig, F. T. et al. 2002. Genetic diversity, mating system and conservation of a Mexican subalpine relict Picea mexicana. Conserv. Genet. 3: 113-122.

Ledig, F. T. et al. 2005. Genic diversity, genetic structure, and mating system of Brewer spruce (Pinaceae), a relict of the Arcto-Tertiary forest. - Am. J. Bot. 92: 1975-1986.

Lewandowski, A. and Burczyk, J. 2000. Mating system and genetic diversity in natural populations of European larch (Lar$i x$ decidua) and stone pine (Pinus cembra) located at higher elevations. - Silvae Genet. 49: 158-161.

Lloyd, D. G. 1979. Some reproductive factors affecting the selection of self-fertilization in plants. - Am. Nat. 113: 67-79.

Mimura, M. and Aitken, S. N. 2007. Increased selfing and decreased effective pollen donor number in peripheral relative to central populations in Picea sitchensis (Pinaceae). - Am. J. Bot. 94: 991-998.

Mitton, J. B. 1992. The dynamic mating systems of conifers. New For. 6: 197-216.

Mitton, J. B. et al. 1997. The pattern of inbreeding in Washoe pine and survival of inbred progeny under optimal environmental conditions. - Silvae Genet. 46: 215-219.

Morgante, M. et al. 1991. Effects of stand density on outcrossing rate in two Norway spruce (Picea abies) populations. - Can. J. Bot. 69: 2704-2708.

Morgante, M. et al. 1993. Selection against inbreds in early life-cycle phases in Pinus leucodermis - Ant. Heredety 70: 622-627.

Neale, D. B. and Adams, W. T. 1985. Allozyme and mating system variation in balsam fir (Abies balsamea) across a continuous elevational transect. - Can. J. Bot. 63: 2448-2453. 
O'Connell, L. M. et al. 2006. Impacts of forest fragmentation on the mating system and genetic diversity of white spruce (Picea glauca) at the landscape level. - Heredity 97: 418-426.

Parraguirre-Lezama, C. et al. 2004. Mating system in four natural populations of Pinus greggii Engelm. - Agrociencia 38: 107-119.

Perry, D. J. and Dancik, B. P. 1986. Mating system dynamics of lodgepole pine in Alberta, Canada. - Silvae Genet. 35: 190-195.

Pichot, C. et al. 2006. Déterminants et conséquences de la qualité génétique des graines et semis lors de la phase initiale de régénération naturelle des peuplements forestiers. - Les actes du BRG 6: 277-297.

Porcher, E. and Lande, R. 2005. The evolution of self-fertilization and inbreeding depression under pollen discounting and pollen limitation. - J. Evol. Biol. 18: 497-508.

Quézel, P. and Médail, F. 2003. Ecologie et biogéographie des forêts du bassin méditerranéen. - Elsevier.

Rajora, O. P. et al. 2000. Indicators of population viability in red spruce, Picea rubens. II. Genetic diversity, population structure, and mating behavior. - Can. J. Bot. 78: 941-956.

Rajora, O. P. et al. 2002. Mating system and reproductive fitness traits of eastern white pine (Pinus strobus) in large, central versus small, isolated, marginal populations. - Can. J. Bot. 80: 1173-1184.

Ritland, K. 2002. Extensions of models for the estimation of mating systems using $\mathrm{n}$ independent loci. - Heredity 88: 221-228.

Robledo-Arnuncio, J. J. et al. 2004. Increased selfing and correlated paternity in a small population of a predominantly outcrossing conifer, Pinus sylvestris. - Mol. Ecol. 13: 2567-2577.
Sagnard, F. 2001. Dynamique de recolonisation des pinèdes pionnières par la hêtraie-sapinière: Etude de la structure des peuplements forestiers et de l'évolution génétique des populations de sapin pectiné (Abies alba Mill.) sur le Mont Ventoux. PhD thesis. - Paul Cézanne Univ., Aix-Marseille III, France.

Schroeder, S. 1989. Outcrossing rates and seed characteristics in damaged natural populations of Abies alba Mill. - Silvae Genet. 38: 185-189.

Shea, K. L. 1987. Effects of population structure and cone production on outcrossing rates in Engelmann spruce and subalpine fir. - Evolution 41: 124-136.

Siegismund, H. R. and Kjaer, E. D. 1997. Outcrossing rates in two stands of noble fir (Abies procera Rehd.) in Denmark. Silvae Genet. 46: 144-146.

Siregar, I. Z. and Hattemer, H. H. 2001. Gene flow and mating system in a seedling seed orchard and a natural stand of Pinus merkusii (Jungh. et de Vriese) in Indonesia. - In: MullerStarck, G. and Schubert, R. (eds), Genetic response of forest systems to changing environmental conditions. Kluwer, pp. 281-292.

Sorensen, F. C. 1994. Frequency of seedlings from natural selffertilization in Pacific Northwest ponderosa pine (Pinus ponderosa Dougl. ex Laws.). - Silvae Genet. 43: 100-108.

Sproule, A. T. and Dancik, B. P. 1996. The mating system of black spruce in north-central Alberta, Canada. - Silvae Genet. 45: 159-164.

Vogl, C. et al. 2002. High resolution analysis of mating systems: inbreeding in natural populations of Pinus radiata. - J. Evol. Biol. 15: 433-439.

Williams, C. G. and Savolainen, O. 1996. Inbreeding depression in conifers: Implications for breeding strategy. - For. Sci. 42: $102-117$ 